\title{
Expedited microwave-assisted $N$-alkylation of isatins utilizing DBU
}

\author{
Carly A. Jordan, Krystyna B.Wieczerzak, Kyle J. Knisley, and Daniel M. Ketcha* \\ Department of Chemistry, Wright State University, 3640 Colonel Glenn Hwy, \\ Dayton, $\mathrm{OH}$ 45435, USA \\ E-mail:aniel.ketcha@wright.edu
}

DOI: http://dx.doi.org/10.3998/ark.5550190.p008.205

\begin{abstract}
The $\mathrm{N}$-alkylation of a variety of isatins with alkyl or benzylic halides can be effected under microwave irradiation in ethanol using 1,8-diazabicyclo[5.4.0] undec-7-ene (DBU) as a base. The conditions employed allow for the expedited synthesis of such substrates wherein the products precipitate from the reaction mixture in high yields and high purity after simple filtration. As will be described, microwave irradiation provides a relatively rapid means of effecting $N$-alkylations of isatin with a variety of benzylic halides, propargyl bromide and ethyl bromoacetate in times ranging from $10-25 \mathrm{~min}$ at $140{ }^{\circ} \mathrm{C}$ in closed vials. This report involves the first reported use of DBU for this purpose, and in contrast to other methods, allows for the facilitated isolation of pure products while avoiding extractive or chromatographic purification steps.
\end{abstract}

Keywords: Isatin, $N$-alkylation, microwave, DBU, expedited synthesis

\section{Introduction}

Increased attention is being devoted to exploiting the chemistry ${ }^{1,2}$ and bioactivity ${ }^{3}$ of the highly diversifiable isatin nucleus. ${ }^{4,5}$ The "privileged" progenitor to other classes of biologically active heterocycles, ${ }^{7,8}$ provides incentive for the development of expedient protocols for the embellishment of this core structure, especially in terms of $\mathrm{N}$-alkylation. ${ }^{9}$ To that end, several groups have devised parallel methods for such an operation, minimizing purification and amenable to automation under thermal or microwave conditions. Noteworthy examples include a parallel microwave procedure employing $\mathrm{K}_{2} \mathrm{CO}_{3} / \mathrm{KI}$ in acetonitrile $\left(160{ }^{\circ} \mathrm{C}, 10 \mathrm{~min}\right){ }^{10}$ and an analogous process in DMF $\left(150{ }^{\circ} \mathrm{C}, 5-15 \mathrm{~min}\right) .{ }^{11}$

Alternatively, with regard to devising highly efficient and rapid solution phase methodologies for the parallel synthesis of diverse isatins, Shuttleworth utilized polymersupported 2-tert-butylimino-2-diethylamino-1,3-dimethylperhydro-1,3,2-diazaphosphorine (BEMP) on polystyrene for the preparation of a library of serine protease inhibitors, ${ }^{12}$ while 
Chibale et al. employed the less expensive solid-supported base potassium fluoride on alumina $\left(\mathrm{KF} / \mathrm{Al}_{2} \mathrm{O}_{3}\right) .{ }^{13}$ More recently, we reported the use of $\mathrm{KF} / \mathrm{Al}_{2} \mathrm{O}_{3}$ in acetonitrile $(\mathrm{ACN})$ for the $N$ alkylation of isatins under thermal conditions or microwave-irradiation $\left(180{ }^{\circ} \mathrm{C}\right) .{ }^{14}$ Whereas all three of the above methods allow for facilitated purification by filtration from the solid bases employed, they also necessitated standard means of workup or purification after that point. It was therefore envisaged that if a soluble organic base were employed in a solvent from which the product might spontaneously crystallize, a substantial saving in time-consuming steps would be realized.

\section{Results and Discussion}

In devising highly efficient and rapid solution phase methodologies for the parallel preparation of diverse isatins, it was envisaged that the use of a soluble base under microwave conditions might constitute a useful expedient. Since it appeared that the $N$-alkylation of isatin had yet to be conducted under microwave irradiation using DBU, it was decided to examine the use of this basic catalyst in ethanol $(\mathrm{EtOH})$ under microwave irradiation in a CEM Discover microwave (300 watts). The initial parameters involved using DBU (1.1 equiv) for the model reaction of isatin $(0.3 \mathrm{~g}, 2.00 \mathrm{mmol})$ and benzyl chloride (1.5 equiv) to yield 1-benzylindoline-2,3-dione in $\mathrm{EtOH}(3 \mathrm{~mL})$ in a microwave vial $(10 \mathrm{~mL})$. Reactions were conducted at temperatures from $120^{\circ} \mathrm{C}$ to $140^{\circ} \mathrm{C}$ in 10 degree increments and at time intervals of 10 and 25 min after which reactions were monitored by GC/MS to ascertain completeness. For the prototype reaction above, it was found that complete conversion was effected at $140^{\circ} \mathrm{C}$ for $10 \mathrm{~min}$. Using these optimal parameters for temperature and time, it was found that increasing the amount of DBU to 1.5 equiv did not result in substantially enhanced conversion. Therefore, these conditions were employed to conduct other $N$-alkylation reactions using isatin and DBU to produce the desired $N$-alkylated isatins (Scheme 1).
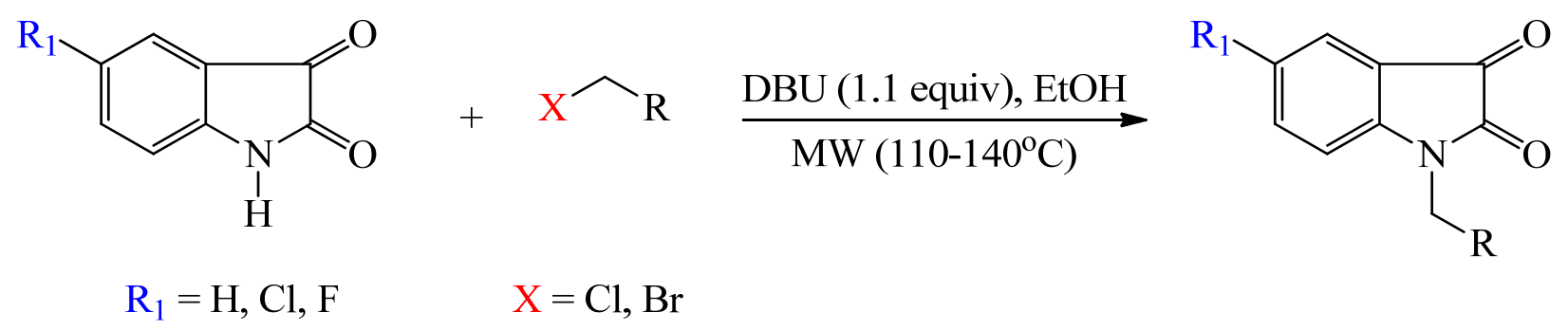

Table 1 displays a summary of the microwave irradiation process providing a rapid means of effecting $N$-alkylations of isatins with a variety of benzylic halides, propargyl bromide, and ethyl bromoacetate. The yields listed are a summation of the pure solid obtained upon the first crystallization and that obtained by chromatographic purification of the filtrate. In all instances, the material obtained by crystallization from the reaction medium was pure, as determined by 
GC/MS and in most cases provided sufficient amounts of material to be carried on in subsequent steps if desired.

In general, alkylation of isatins bearing electron-withdrawing substituents at the C-5 position could be effected at lower temperatures albeit with longer reaction times. Additionally, electron withdrawing groups on the benzylic halides also served to enhance observed reactivity in comparison to those rings not similarly substituted or the propargyl halide. In the case of the $N$ propargylation of isatin itself (entry 2), it was determined that the use of a ramp technique in the microwave allowed for a higher yield but such a protocol was unnecessary in other reactions. It is also noteworthy that ethyl 2-(5-chloro-2,3-dioxoindolin-1-yl)acetate (6) formed rapidly at room temperature upon mixing of the reactants.<smiles>[R]c1ccc2c(c1)C(=O)C(=O)N2</smiles>

$\mathrm{R}^{1}-\mathrm{H}, \mathrm{Cl}, \mathrm{F}$

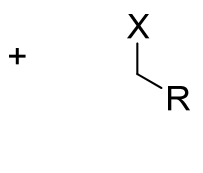

$\mathrm{X}=\mathrm{Cl}, \mathrm{Br}$
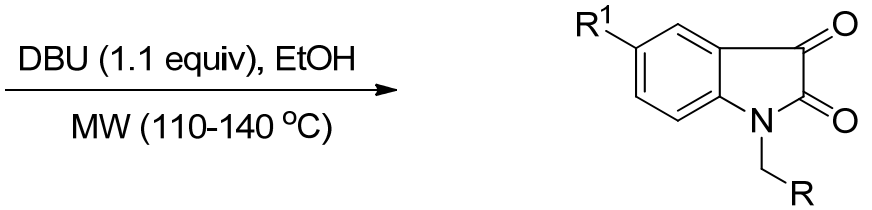

\section{Scheme 1}

Table 1. Optimization of reaction conditions

\begin{tabular}{|c|c|c|c|c|c|c|c|}
\hline \multirow{2}{*}{ Entry } & \multicolumn{2}{|c|}{$\begin{array}{l}\text { Substituents in } \\
\text { Scheme } 1\end{array}$} & \multirow{2}{*}{$\begin{array}{l}\text { Time } \\
(\min )\end{array}$} & \multirow{2}{*}{$\begin{array}{l}\text { Temp. } \\
\left({ }^{\circ} \mathrm{C}\right)\end{array}$} & \multirow{2}{*}{$\mathrm{MP}\left({ }^{\circ} \mathrm{C}\right)$} & \multirow{2}{*}{ Yield } & \multirow{2}{*}{ Lit. $\mathrm{MP}\left({ }^{\circ} \mathrm{C}\right)$} \\
\hline & $\mathrm{R}^{1}$ & $\mathrm{R}$ & & & & & \\
\hline 1 & $\mathrm{H}$ & $\mathrm{CO}_{2} \mathrm{Et}$ & 10 & 140 & $105-110$ & $47 \%$ & $124-129^{14}$ \\
\hline 2 & $\mathrm{H}$ & $\mathrm{C} \equiv \mathrm{CH}$ & 10 & 140 & $147-149$ & $81 \%$ & $157-158^{15}$ \\
\hline 3 & $\mathrm{H}$ & $\mathrm{Ph}$ & 10 & 140 & $129-134$ & $61 \%$ & $128-133^{14}$ \\
\hline 4 & $\mathrm{H}$ & $2,6-\mathrm{Cl}_{2} \mathrm{C}_{6} \mathrm{H}_{3}$ & 10 & 140 & $181-186$ & $93 \%$ & $175-180^{14}$ \\
\hline 5 & $\mathrm{H}$ & $2,6-\mathrm{F}_{2} \mathrm{C}_{6} \mathrm{H}_{3}$ & 10 & 140 & $155-158$ & $84 \%$ & $154-156^{14}$ \\
\hline 6 & $\mathrm{Cl}$ & $\mathrm{CO}_{2} \mathrm{Et}$ & 20 & 120 & $126-128$ & $68 \%$ & $130-135^{14}$ \\
\hline 7 & $\mathrm{Cl}$ & $\mathrm{C} \equiv \mathrm{CH}$ & 20 & 120 & $157-159$ & $64 \%$ & Ref. 16 \\
\hline 8 & $\mathrm{Cl}$ & $\mathrm{Ph}$ & 20 & 120 & $130-133$ & $71 \%$ & $134^{14}$ \\
\hline 9 & $\mathrm{Cl}$ & $2,6-\mathrm{Cl}_{2} \mathrm{C}_{6} \mathrm{H}_{3}$ & 20 & 120 & $232-235$ & $84 \%$ & $233-235^{14}$ \\
\hline 10 & $\mathrm{Cl}$ & $2,6-\mathrm{F}_{2} \mathrm{C}_{6} \mathrm{H}_{3}$ & 20 & 120 & $171-174$ & $72 \%$ & $172-177^{14}$ \\
\hline 11 & $\mathrm{~F}$ & $\mathrm{Ph}$ & 25 & 120 & $128-131$ & $88 \%$ & $130-133^{17}$ \\
\hline 12 & $\mathrm{~F}$ & $2,6-\mathrm{F}_{2} \mathrm{C}_{6} \mathrm{H}_{3}$ & 25 & 120 & $132-134$ & $82 \%$ & Ref. 10 \\
\hline
\end{tabular}


Thus, the use of the soluble base DBU in conjunction with a suitable crystallizing solvent under microwave conditions allows for the expedited construction of a small library of $\mathrm{N}$ alkylated isatins which could be isolated in a pure state and in synthetically useful yields by simple filtration.

\section{Conclusions}

The development of a convenient synthesis of $\mathrm{N}$-alkylated isatins with various alkyl halides under microwave irridiation was examined using the soluble liquid base DBU. With the use of this soluble base, an expedited synthetic protocol was devised wherein product isolation could be effected by simple filtration of the reaction mixture.

\section{Experimental Section}

General. Melting points were determined via the use of open capillaries with an Electrothermal melting point apparatus. The ${ }^{1} \mathrm{H}$ and ${ }^{13} \mathrm{C}$ NMR data were obtained on a Bruker Avance $300 \mathrm{MHz}$ NMR in DMSO- $d_{6}$ solution. Chemical shifts for proton NMR are reported in $\delta$ (ppm) downfield from tetramethylsilane as an internal standard and ${ }^{13} \mathrm{C}$ NMR shifts are calibrated on the DMSO$\mathrm{d}_{6}$ resonance at $39.50 \mathrm{ppm}$. Coupling constants $(J)$ are in $\mathrm{Hz}$. The following abbreviations are used to describe peak patterns where appropriate: $s$, singlet; $d$, doublet; dd, double doublet; $t$, triplet; q, quartet; dt, double triplet; m, multiplet. GC/MS measurements were performed using Hewlett-Packard 6890 Series GC with auto injection and mass fragments are reported as mass per charge, $\mathrm{m} / \mathrm{z}$. The GC was coupled with a mass spectrometer with Hewlett-Packard 5973 mass selective detector/quadrupole system. Flash column (Silica Gel, Premium $R_{f}, 200-400$ mesh, Sorbent Technologies) and thin layer chromatography reactions were performed on silica gel with indicated solvent systems. Microwave reactions were performed in a monomode MARS Glasschem 300 Watt system by CEM with sample absorption set to "normal".

Note: Identities of compounds previously prepared in this laboratory ${ }^{14}$ were confirmed by GC/MS as well as ${ }^{1} \mathrm{H}$ and ${ }^{13} \mathrm{C}$ NMR comparisons.

Ethyl 2-(2,3-dioxoindolin-1-yl)acetate (1). To a $10 \mathrm{~mL}$ microwave vial charged with ethanol (3 $\mathrm{mL})$ and a magnetic stir bar was added isatin $(0.3111 \mathrm{~g}, 2.11 \mathrm{mmol}), \mathrm{DBU}(325 \mu \mathrm{L}, 1.1 \mathrm{eq})$ and ethyl bromoacetate $(257 \mu \mathrm{L}, 1.1 \mathrm{eq})$. The reaction vessel was sealed and heated under microwave irradiation in standard mode for $10 \mathrm{~min}$ at $140{ }^{\circ} \mathrm{C}$ with a pre-stirring $30 \mathrm{sec}$. After cooling to $\mathrm{rt}$, the reaction vessel was allowed to stand overnight in a freezer and then vacuum filtered to afford the pure (TLC, GC/MS) product as a light orange solid $(0.1049 \mathrm{~g}, 21 \%)$ : $\mathrm{mp}$ 105-110 ${ }^{\circ} \mathrm{C}$ (lit. ${ }^{14} \mathrm{mp} 124-129{ }^{\circ} \mathrm{C}$ ); $\mathrm{R}_{\mathrm{f}}=0.21$ (hexanes/EtOAc, 1:1). The filtrate was then evaporated under reduced pressure to afford an oil which was purified by silica gel 
chromatography (hexanes/EtOAc, $70: 30)$ to provide additional product $(0.1130 \mathrm{~g})$ for a combined overall yield of 47\%; ${ }^{1} \mathrm{H}$ NMR $(300 \mathrm{MHz}$ DMSO-d $) \delta 7.62(\mathrm{td}, J=7.83 \mathrm{~Hz}, 1.35 \mathrm{~Hz}$, $1 \mathrm{H}), 7.55 \mathrm{ppm}(\mathrm{dd}, J=7.6 \mathrm{~Hz}, 0.8 \mathrm{~Hz}, 1 \mathrm{H}), 7.20(\mathrm{td}, J=7.5 \mathrm{~Hz}, 0.7 \mathrm{~Hz}, 1 \mathrm{H}), 6.88(\mathrm{~d}, J=7.9$ $\mathrm{Hz}, 1 \mathrm{H}), 4.54(\mathrm{~s}, 2 \mathrm{H}), 4.22(\mathrm{q}, J=7.2 \mathrm{~Hz}, 2 \mathrm{H}), 1.31(\mathrm{t}, J=7.0 \mathrm{~Hz}, 3 \mathrm{H}) ;{ }^{13} \mathrm{C} \mathrm{NMR}(75 \mathrm{MHz}$ DMSO- $\left.d_{6}\right) \delta 182.3,167.1,158.2,150.1,138.5,124.5,123.7,117.3,111.3,61.3,41.1,14.0$ ppm; $\operatorname{MS}(\mathrm{m} / \mathrm{z}) 233\left(\mathrm{M}^{+}\right), 132(100 \%)$.

1-(Prop-2-yn-1-yl)indoline-2,3-dione (2). To a $10 \mathrm{~mL}$ microwave vial charged with ethanol (3 $\mathrm{mL}$ ) and a magnetic stir bar was added isatin (0.3064 g, $2.08 \mathrm{mmol})$, DBU (342 $\mu \mathrm{L}, 1.1 \mathrm{eq})$ and propargyl bromide $(210 \mu \mathrm{L}, 1.1 \mathrm{eq})$. The reaction vessel was sealed and heated under microwave irradiation in dynamic mode where the mixture was heated in 5 stages with pressure and high power being held constant throughout the run time at 130 psi and 200 watts, respectively. The first stage of heating was set at $110{ }^{\circ} \mathrm{C}$ for $3 \mathrm{~min}$, the second stage of heating was set at $120{ }^{\circ} \mathrm{C}$ for $2 \mathrm{~min}$, the third stage of heating was set at $100{ }^{\circ} \mathrm{C}$ for $1 \mathrm{~min}$, the fourth stage of heating was set at $120{ }^{\circ} \mathrm{C}$ for $2 \mathrm{~min}$, and the final stage of heating was set at $95{ }^{\circ} \mathrm{C}$ for $6 \mathrm{~min}$. The first stage had high stirring while the final 4 stages had a low stir setting. The pre-stirring for this setup was high for $1 \mathrm{~min}$. After cooling to $\mathrm{rt}$, the reaction vessel was placed in the freezer overnight and vacuum-filtered to afford the pure product (GCMS/TLC) as an orange solid (0.1277 $\mathrm{g}, 33.1 \%)$ : mp 147-149 ${ }^{\circ} \mathrm{C}$ (lit. ${ }^{15} \mathrm{mp} 157-158{ }^{\circ} \mathrm{C}$ ); $\mathrm{R}_{\mathrm{f}}=0.46$ (hexanes/EtOAc, 1:1). The filtrate was then evaporated under reduced pressure and purified by silica gel chromatography (hexanes/EtOAc, $70: 30)$ to give additional product $(0.1844 \mathrm{~g})$ for a combined overall yield of $81 \% ;{ }^{1} \mathrm{H}$ NMR $(300$ MHz DMSO-d $) \delta 7.75(\mathrm{td}, J=1.3 \mathrm{~Hz}, J=7.8 \mathrm{~Hz}, 1 \mathrm{H}), 7.61(\mathrm{dd}, J=0.5 \mathrm{~Hz}, J=1.2 \mathrm{~Hz}, 1 \mathrm{H})$, $7.58(\mathrm{dd}, J=0.5 \mathrm{~Hz}, J=1.2 \mathrm{~Hz}, 1 \mathrm{H}), 7.24(\mathrm{~d}, J=7.9 \mathrm{~Hz}, 1 \mathrm{H}), 7.21$ (dd, $J=0.8 \mathrm{~Hz}, J=15.0 \mathrm{~Hz}$, $1 \mathrm{H}), 7.19(\mathrm{~d}, J=0.7 \mathrm{~Hz}, 1 \mathrm{H}), 4.55(\mathrm{~d}, J=2.5 \mathrm{~Hz}, 2 \mathrm{H}) ;{ }^{13} \mathrm{C}$ NMR $\left(75 \mathrm{MHz}\right.$ DMSO-d $\left.d_{6}\right) \delta 182.5$, 157.3, 149.4, 138.1, 124.5, 123.6, 117.6, 111.1, 77.2, 74.8, 28.9; MS: m/z $185\left(\mathrm{M}^{+}\right), 129$ (100\%).

1-Benzylindoline-2,3-dione (3). To a $10 \mathrm{~mL}$ microwave vial charged with ethanol (3 $\mathrm{mL})$ and a magnetic stir bar was added isatin $(0.2943 \mathrm{~g}, 2.00 \mathrm{mmol})$, DBU (329 $\mu \mathrm{L}, 1.1 \mathrm{eq})$ and benzyl chloride $(257 \mu \mathrm{L}, 1.1 \mathrm{eq})$. The reaction vessel was sealed and heated under microwave irradiation in standard mode for $10 \mathrm{~min}$ at $140{ }^{\circ} \mathrm{C}$ with a pre-stirring $30 \mathrm{sec}$. After cooling to rt, the reaction vessel was allowed to stand overnight in a freezer and then vacuum filtered to afford the pure (TLC, GC/MS) product as a light orange solid (0.0536 g, 11\%): mp 129-134 ${ }^{\circ} \mathrm{C}$ (lit. ${ }^{14} \mathrm{mp} 128$ $133{ }^{\circ} \mathrm{C}$ ); $\mathrm{R}_{\mathrm{f}}=0.41$ (hexanes/EtOAc, 1:1). The filtrate was then evaporated under reduced pressure to afford an oil which was purified by silica gel chromatography (hexanes/EtOAc, $70: 30)$ to provide additional product $(0.2895 \mathrm{~g}$ ) for a combined overall yield of $61 \%$; $1 \mathrm{H} \mathrm{NMR}$ $(300 \mathrm{MHz}$ DMSO-d $) \delta 7.60(\mathrm{td}, J=7.8 \mathrm{~Hz}, 1.3 \mathrm{~Hz}, 1 \mathrm{H}), 7.44(\mathrm{dd}, J=7.2 \mathrm{~Hz}, 0.8 \mathrm{~Hz}, 1 \mathrm{H})$, 7.37-7.28 (m, 5-H), $7.14(\mathrm{td}, J=7.5 \mathrm{~Hz}, 0.8 \mathrm{~Hz}, 1 \mathrm{H}), 6.98(\mathrm{~d}, J=7.9 \mathrm{~Hz}, 1 \mathrm{H}), 4.91(\mathrm{~s}, 1 \mathrm{H}) ;{ }^{13} \mathrm{C}$ NMR (75 MHz DMSO-d $)_{6} \delta 183.1,158.3,150.3,137.9,135.5,128.6,127.5,127.3,124.4$, 123.3, 117.7, 111.0, 42.9; MS (m/z) $237\left(\mathrm{M}^{+}\right), 146$ (100\%).

1-(2,6-Dichlorobenzyl)indoline-2,3-dione (4). To a $10 \mathrm{~mL}$ microwave vial charged with ethanol ( $3 \mathrm{~mL})$ and a magnetic stir bar was added isatin $(0.3062 \mathrm{~g}, 2.08 \mathrm{mmol})$, DBU (342 $\mu \mathrm{L}, 1.1 \mathrm{eq})$ and 2,6-dichlorobenzyl bromide $(0.5711 \mathrm{~g}, 1.1 \mathrm{eq})$. The reaction vessel was sealed and heated 
under microwave irradiation in standard mode for $10 \mathrm{~min}$ at $140{ }^{\circ} \mathrm{C}$ with a pre-stirring $30 \mathrm{sec}$. After cooling to $\mathrm{rt}$, the reaction vessel was allowed to stand overnight in a freezer and then vacuum filtered to afford the pure (TLC, GC/MS) product as an orange solid $(0.4151 \mathrm{~g}, 65 \%)$ : mp 181-186 ${ }^{\circ} \mathrm{C}$ (lit. ${ }^{14} \mathrm{mp} 175-180{ }^{\circ} \mathrm{C}$ ); $\mathrm{R}_{\mathrm{f}}=0.57$ (hexanes/EtOAc, 1:1). The filtrate was then evaporated under reduced pressure and purified by silica gel chromatography (hexanes/EtOAc, $70: 30)$ to provide additional product $(0.1787 \mathrm{~g})$ for a combined overall yield of $93 \%$; ${ }^{1} \mathrm{H} \mathrm{NMR}$ $\left(300 \mathrm{MHz}, \mathrm{DMSO}-d_{6}\right) \delta 7.65(\mathrm{td}, J=7.8 \mathrm{~Hz}, 1.4 \mathrm{~Hz}, 1 \mathrm{H}), 7.58 \mathrm{ppm}(\mathrm{dd}, J=7.5 \mathrm{~Hz}, 0.8 \mathrm{~Hz}$, $1 \mathrm{H}), 7.44(\mathrm{~d}, J=8.31 \mathrm{~Hz}, 1 \mathrm{H}), 7.15(\mathrm{~d}, J=7.23 \mathrm{~Hz}, 1 \mathrm{H}), 7.13(\mathrm{t}, J=6.51 \mathrm{~Hz}, 1 \mathrm{H}), 7.08(\mathrm{t}, J=$ $7.56 \mathrm{~Hz}, 1 \mathrm{H}), 6.93(\mathrm{~d}, J=7.89 \mathrm{~Hz}, 1 \mathrm{H}), 5.26(\mathrm{~s}, 2 \mathrm{H}) ;{ }^{13} \mathrm{C}$ NMR $(75 \mathrm{MHz}$ DMSO-d 6 ) $\delta 182.7$, $157.7,150.6,138.4,135.4,130.8,129.7,129.1,124.7,123.4,117.9,110.8,40.4 ; \mathrm{MS}(\mathrm{m} / \mathrm{z}) 305$ $\left(\mathrm{M}^{+}\right), 270(100 \%)$.

1-(2,6-Difluorobenzyl)indoline-2,3-dione (5). To a $10 \mathrm{~mL}$ microwave vial charged with ethanol (3 mL) and a magnetic stir bar was added isatin $(0.2962 \mathrm{~g}, 2.01 \mathrm{mmol})$, DBU (329 $\mu \mathrm{L}, 1.1 \mathrm{eq})$ and 2,6-difluorobenzyl bromide $(0.5278 \mathrm{~g}, 1.1 \mathrm{eq})$. The reaction vessel was sealed and heated under microwave irradiation in standard mode for $10 \mathrm{~min}$ at $140{ }^{\circ} \mathrm{C}$ with a pre-stirring $30 \mathrm{sec}$. After cooling to $\mathrm{rt}$, the reaction vessel was allowed to stand overnight in a freezer and then vacuum filtered to afford the pure (TLC, GC/MS) product as yellow-orange solid $(0.2469 \mathrm{~g}$, 45\%): $\mathrm{mp} 155-158{ }^{\circ} \mathrm{C}$ (lit. ${ }^{14} \mathrm{mp} 154-156{ }^{\circ} \mathrm{C}$ ); $\mathrm{R}_{\mathrm{f}}=0.32$ (hexanes/EtOAc, $1: 1$ ). The filtrate was then evaporated under reduced pressure to afford an oil which was purified by silica gel chromatography (hexanes/EtOAc, 70:30) to provide additional product $(0.2100 \mathrm{~g})$ for a combined overall yield of 84\%; ${ }^{1} \mathrm{H}$ NMR (300 MHz DMSO- $\left.d_{6}\right) \delta 7.70(\mathrm{t}, J=7.8 \mathrm{~Hz}, 1 \mathrm{H}), 7.57$ ppm (dd, $J=7.5 \mathrm{~Hz}, 0.8 \mathrm{~Hz}, 1 \mathrm{H}), 7.49(\mathrm{~m}, 1 \mathrm{H}), 7.17(\mathrm{t}, J=7.5 \mathrm{~Hz}, 1 \mathrm{H}), 6.98(\mathrm{t}, J=8.2 \mathrm{~Hz}, 1 \mathrm{H})$, $4.96(\mathrm{~s}, 1 \mathrm{H}) ;{ }^{13} \mathrm{C}$ NMR $(75 \mathrm{MHz}$ DMSO-d 6 ) $\delta: 182.8,162.7-159.3(\mathrm{dd}, J=7.8 \mathrm{~Hz}), 157.6,150.3$, $138.3,130.8-130.6$ (t, $J=10.4 \mathrm{~Hz}), 124.6,123.4,117.6,111.9-111.65$ (d, $J=7.4 \mathrm{~Hz}), 110.8$, 110.40-110.36 (t, $J=7.8 \mathrm{~Hz}), 32.1$; MS $(\mathrm{m} / \mathrm{z}): 273\left(\mathrm{M}^{+}\right), 146(100 \%)$.

Ethyl 2-(5-chloro-2,3-dioxoindolin-1-yl)acetate (6). To a $10 \mathrm{~mL}$ microwave vial charged with ethanol $(3 \mathrm{~mL})$ and a magnetic stir bar was added 5-chloroisatin (0.3689 g, $2.00 \mathrm{mmol})$, DBU (329 $\mu \mathrm{L}, 1.1 \mathrm{eq})$ and ethyl bromoacetate $(243 \mu \mathrm{L}, 1.1 \mathrm{eq})$. The reaction vessel was sealed and heated under microwave irradiation in standard mode for $20 \mathrm{~min}$ at $120{ }^{\circ} \mathrm{C}$ with a pre-stirring 30 sec. After cooling to $\mathrm{rt}$, the reaction vessel was allowed to stand overnight in a freezer and then vacuum filtered to afford the pure (TLC, GC/MS) product as a light orange solid (0.1662 g, 31\%): mp 126-128 ${ }^{\circ} \mathrm{C}$ (lit. ${ }^{14} \mathrm{mp} 130-135{ }^{\circ} \mathrm{C}$ ); $\mathrm{R}_{\mathrm{f}}=0.63$ (hexanes/EtOAc, 1:1). The filtrate was then evaporated under reduced pressure to afford an oil which was purified by silica gel chromatography (hexanes/EtOAc, 70:30) to provide additional product $(0.1965 \mathrm{~g})$ for a combined overall yield of $68 \%$; ${ }^{1} \mathrm{H}$ NMR $(300 \mathrm{MHz}$ DMSO-d $) \delta 7.77 \mathrm{ppm}(\mathrm{dd}, J=8.6 \mathrm{~Hz}, 2.2$ $\mathrm{Hz}, 1 \mathrm{H}), 7.68(\mathrm{~d}, J=2.0 \mathrm{~Hz}, 1 \mathrm{H}), 7.26(\mathrm{~d}, J=8.5 \mathrm{~Hz}, 1 \mathrm{H}), 4.62(\mathrm{~s}, 2 \mathrm{H}), 4.20$ (q, $7.1 \mathrm{~Hz}, 2 \mathrm{H})$, $1.23(\mathrm{t}, J=7.1 \mathrm{~Hz}, 3 \mathrm{H}) ;{ }^{13} \mathrm{C}$ NMR $(75 \mathrm{MHz}$ DMSO-d 6$) \delta 181.5,167.3,157.8,148.9,137.3$, 127.9, 124.1, 118.6, 112.9, 61.4, 41.3, 13.9; $\mathrm{MS}(\mathrm{m} / \mathrm{z}) 267\left(\mathrm{M}^{+}\right), 28(100 \%)$.

5-Chloro-1-(prop-2-yn-1-yl)indoline-2,3-dione ${ }^{\mathbf{1 6}}$ (7). To a $10 \mathrm{~mL}$ microwave vial charged with ethanol $(3 \mathrm{~mL})$ and a magnetic stir bar was added isatin $(0.3632 \mathrm{~g}, 2.00 \mathrm{mmol})$, DBU $(329 \mu \mathrm{L}$, 
$1.1 \mathrm{eq})$ and propargyl bromide $(201 \mu \mathrm{L}, 1.1 \mathrm{eq})$. The reaction vessel was sealed and heated under microwave irradiation in standard mode for $20 \mathrm{~min}$ at $110{ }^{\circ} \mathrm{C}$ with pre-stirring $30 \mathrm{sec}$. After cooling to rt, the reaction vessel was placed in the freezer overnight and then vacuum filtered to afford a pure (GCMS/TLC) orange solid $(0.0521 \mathrm{~g}, 12 \%): \mathrm{mp} 157-159 \quad{ }^{\circ} \mathrm{C} ; \mathrm{R}_{\mathrm{f}}=$ 0.51(hexanes/EtOAc, 1:1). The filtrate was then evaporated under reduced pressure to afford an orange oil which was purified by silica gel chromatography (hexanes/EtOAc, 70:30) to give additional product $(0.3145 \mathrm{~g})$ for a combined overall yield of 64\%: ${ }^{1} \mathrm{H}$ NMR (300 MHz DMSO$\left.d_{6}\right) \delta 7.79(\mathrm{dd}, J=2.2 \mathrm{~Hz}, J=8.4 \mathrm{~Hz}, 1 \mathrm{H}), 7.65(\mathrm{~d}, J=2.1 \mathrm{~Hz}, 1 \mathrm{H}), 7.27(\mathrm{~d}, J=8.4 \mathrm{~Hz}, 1 \mathrm{H})$, $4.56(\mathrm{~d}, J=2.5 \mathrm{~Hz}, 2 \mathrm{H}), 4.35(\mathrm{t}, J=5.0,1 \mathrm{H}) ;{ }^{13} \mathrm{C} \mathrm{NMR}\left(75 \mathrm{MHz} \mathrm{DMSO}-d_{6}\right) \delta 181.4,157.1$, 147.9, 136.9, 127.8, 124.0, 119.1, 112.8, 77.0, 75.1, 29.1; MS (m/z) $219\left(\mathrm{M}^{+}\right), 28$ (100 \%). Anal. Calcd for $\mathrm{C}_{11} \mathrm{H}_{6} \mathrm{ClNO}_{2}$ : C, 60.16; H, 2.75; N, 6.38; Found: C, 59.98; H, 2.73; N, 6.33 .

1-Benzyl-5-chloroindoline-2,3-dione (8). To a $10 \mathrm{~mL}$ microwave vial charged with ethanol (3 $\mathrm{mL})$ and a magnetic stir bar was added 5-chloroisatin $(0.3785 \mathrm{~g}, 2.08 \mathrm{mmol})$, DBU (329 $\mu \mathrm{L}, 1.1$ eq) and benzyl chloride $(257 \mu \mathrm{L}, 1.1 \mathrm{eq})$. The reaction vessel was sealed and heated under microwave irradiation in standard mode for $20 \mathrm{~min}$ at $140{ }^{\circ} \mathrm{C}$ with a pre-stirring $30 \mathrm{sec}$. After cooling to $\mathrm{rt}$, the reaction vessel was placed in the freezer overnight but did not afford a solid. The resulting orange-red liquid was then evaporated under reduced pressure to afford an orange oil which was purified by silica gel chromatography (hexanes/EtOAc, 70:30) to afford a pure (GC-MS/TLC) orange red solid (0.3875 g, 71\%): mp 130-133 ${ }^{\circ} \mathrm{C}$ (lit. $\left.{ }^{14} \mathrm{mp} 134{ }^{\circ} \mathrm{C}\right) ; \mathrm{R}_{\mathrm{f}}=0.65$ (hexanes:EtOAc,1:1). ${ }^{1} \mathrm{H}$ NMR (300 MHz DMSO-d 6 ) $\delta 7.63(\mathrm{dd}, J=8.4 \mathrm{~Hz}, 2.2 \mathrm{~Hz}, 1 \mathrm{H}), 7.44$ $\operatorname{ppm}(\mathrm{d}, J=2.2 \mathrm{~Hz}, 1 \mathrm{H}), 7.37-7.28(\mathrm{~m}, 5-\mathrm{H}), 6.98(\mathrm{~d}, J=8.3 \mathrm{~Hz}, 1 \mathrm{H}), 4.91(\mathrm{~s}, 2 \mathrm{H}) ;{ }^{13} \mathrm{C}$ NMR $(75$ MHz DMSO- $\left.d_{6}\right) \delta 181.9,158.1,148.8,136.7,135.1,129.7,128.6,127.5,127.2,123.9,119.1$, 112.6, 42.9; $\mathrm{MS}(\mathrm{m} / \mathrm{z}) 271\left(\mathrm{M}^{+}\right), 180(100 \%)$.

1-(2,6-Dichlorobenzyl)-5-chloroindoline-2,3-dione (9). To a $10 \mathrm{~mL}$ microwave vial charged with ethanol $(3 \mathrm{~mL})$ a magnetic stir bar was added 5-chloroisatin $(0.3658 \mathrm{~g}, 2.01 \mathrm{mmol})$, DBU (329 $\mu \mathrm{L}, 1.1 \mathrm{eq})$ and 2,6-dichlorobenzyl bromide $(0.5310 \mathrm{~g}, 1.1 \mathrm{eq})$. The reaction vessel was sealed and heated under microwave irradiation in standard mode for $20 \mathrm{~min}$ at $120^{\circ} \mathrm{C}$ with a prestirring $30 \mathrm{sec}$. After cooling to $\mathrm{rt}$, the reaction vessel was placed in the freezer for $2 \mathrm{~h}$ and then vacuum filtered to afford the pure (TLC, GC/MS) product as an orange-red solid $(0.5772 \mathrm{~g}$, 84\%): mp 232-235 ${ }^{\circ} \mathrm{C}$ (lit. ${ }^{14} \mathrm{mp} 233-235{ }^{\circ} \mathrm{C}$ ); $\mathrm{R}_{\mathrm{f}}=0.60$ (hexanes/EtOAc, 1:1). ${ }^{1} \mathrm{H}$ NMR (300 MHz DMSO-d $) \delta 7.73$ ppm (dd, $J=8.5 \mathrm{~Hz}, 2.3 \mathrm{~Hz}, 1 \mathrm{H}), 7.65(\mathrm{~d}, J=2.3 \mathrm{~Hz}, 1 \mathrm{H}), 7.55(\mathrm{~d}, J=$ $8.0 \mathrm{~Hz}, 1 \mathrm{H}), 7.44(\mathrm{t}, 7.9 \mathrm{~Hz}, 1 \mathrm{H}), 7.01(\mathrm{~d}, J=8.4 \mathrm{~Hz}, 1 \mathrm{H}), 5.12(\mathrm{~s}, 2 \mathrm{H}) ;{ }^{13} \mathrm{C} \mathrm{NMR}(75 \mathrm{MHz}$ DMSO-d $\left.{ }_{6}\right) \delta 181.6,157.5,149.2,137.3,135.4,130.8,129.5,129.1,127.6,124.2,118.9,112.6$, 40.4; $\mathrm{MS}(\mathrm{m} / \mathrm{z}) 339\left(\mathrm{M}^{+}\right), 180(100 \%)$.

1-(2,6-Difluorobenzyl)-5-chloroindoline-2,3-dione (10). To a $10 \mathrm{~mL}$ microwave vial charged with ethanol $(3 \mathrm{~mL})$ and a magnetic stir bar was added 5-chloroisatin $(0.3650 \mathrm{~g}, 2.00 \mathrm{mmol})$, DBU (329 $\mu \mathrm{L}, 1.1 \mathrm{eq})$ and 2,6-difluorobenzyl bromide $(0.4554 \mathrm{~g}, 1.1 \mathrm{eq})$. The reaction vessel was sealed and heated under microwave irradiation in standard mode for $20 \mathrm{~min}$ at $120{ }^{\circ} \mathrm{C}$ with a pre-stirring $30 \mathrm{sec}$. After cooling to $\mathrm{rt}$, the reaction vessel was placed in the freezer overnight and then vacuum filtered to afford the pure (TLC, GC/MS) product as a red solid $(0.4091 \mathrm{~g}, 66 \%)$ : 
mp 171-174 ${ }^{\circ} \mathrm{C}$ (lit. ${ }^{14} \mathrm{mp} 172-177{ }^{\circ} \mathrm{C}$ ); $\mathrm{R}_{\mathrm{f}}=0.56$ (hexanes:EtOAc, 1:1). A second crop afforded additional product $(0.0339 \mathrm{~g})$ for a combined overall yield of $72 \%$. ${ }^{1} \mathrm{H}$ NMR (300 MHz DMSO$\left.d_{6}\right) \delta 7.76 \mathrm{ppm}(\mathrm{dd}, J=2.2 \mathrm{~Hz}, J=8.5 \mathrm{~Hz}, 1 \mathrm{H}), 7.63(\mathrm{~d}, 2.2 \mathrm{~Hz}, 1 \mathrm{H}), 7.49-7.39(\mathrm{~m}, 1 \mathrm{H}), 7.15(\mathrm{t}$, $J=8.2 \mathrm{~Hz}, 1 \mathrm{H}), 7.10(\mathrm{~d}, 8.6 \mathrm{~Hz}, 1 \mathrm{H}), 4.94(\mathrm{~s}, 2 \mathrm{H}){ }^{13} \mathrm{C}$ NMR $(75 \mathrm{MHz}$ DMSO-d 6 ) $\delta 181.7,162.7-$ $159.4(\mathrm{dd}, J=8.2 \mathrm{~Hz}), 157.5,148.8,137.1,130.9-130.6(\mathrm{t}, J=10.5 \mathrm{~Hz}), 127.6,124.0,119.0$, 112.2-112.1 (t, $J=2.6 \mathrm{~Hz}), 111.9-111.6(\mathrm{~d}, J=17.8 \mathrm{~Hz}), 110.6,32.2$; MS ( $\mathrm{m} / \mathrm{z}) 307\left(\mathrm{M}^{+}\right), 127$ $(100 \%)$.

1-Benzyl-5-fluoroindoline-2,3-dione (11). To a $10 \mathrm{~mL}$ microwave vial charged with ethanol (3 $\mathrm{mL})$ and a magnetic stir bar was added 5-fluoroisatin $(0.3310 \mathrm{~g}, 2.00 \mathrm{mmol})$, DBU (330 $\mu \mathrm{L}, 1.1$ eq) and benzyl chloride $(254 \mu \mathrm{L}, 1.1 \mathrm{eq})$. The reaction vessel was sealed and heated under microwave irradiation in standard mode for $25 \mathrm{~min}$ at $120{ }^{\circ} \mathrm{C}$ with a pre-stirring of $30 \mathrm{sec}$. After cooling to room temperature, the reaction vessel was placed in the freezer overnight and then vacuum filtered to afford a pure (GCMS/TLC) dark red solid (0.1408 g, 28\%): mp 128-131 ${ }^{\circ} \mathrm{C}$ (lit. ${ }^{17} \mathrm{mp} 130-133{ }^{\circ} \mathrm{C}$ ); $\mathrm{R}_{\mathrm{f}}=0.64$ (hexanes:EtOAc, 1:1). The filtrate was then evaporated under reduced pressure to afford a red oil which was purified by silica gel chromatography (hexanes/EtOAc, 70:30) to give a dark red solid (0.3073 g) for a combined overall yield of 88\%: ${ }^{1} \mathrm{H}$ NMR (300 MHz DMSO-d $\left.)\right) \delta .57 \mathrm{ppm}(\mathrm{d}, J=2.0 \mathrm{~Hz}, 1 \mathrm{H}), 7.50$ (dd, $J=8.2 \mathrm{~Hz}, 2.2 \mathrm{~Hz}$, 1H), 7.39-7.28 (m, 1H), $6.96(\mathrm{t}, J=8.1 \mathrm{~Hz}, 1 \mathrm{H}), 6.75(\mathrm{~d}, J=8.5 \mathrm{~Hz}, 1 \mathrm{H}), 4.94(\mathrm{~s}, 2 \mathrm{H}) ;{ }^{13} \mathrm{C} \mathrm{NMR}$ $(75 \mathrm{MHz}$ DMSO-d 6$) \delta 182.4,160.09-156.86(\mathrm{~d}, J=241 \mathrm{~Hz}), 158.35-158.33(\mathrm{~d}, J=1.4 \mathrm{~Hz})$, $146.5-146.4(\mathrm{~d}, J=1.6 \mathrm{~Hz}), 135.3,128.6,127.5,127.3,123.9-123.6(\mathrm{~d}, J=24.0 \mathrm{~Hz}), 118.7-$ $118.6(\mathrm{~d}, J=7.2 \mathrm{~Hz}), 112.4-112.3(\mathrm{~d}, J=7.4 \mathrm{~Hz}), 111.6-111.3(\mathrm{~d}, J=24.3 \mathrm{~Hz}), 42.9 ; \mathrm{MS}(\mathrm{m} / \mathrm{z})$ $255\left(\mathrm{M}^{+}\right), 164(100 \%)$.

1-(2,6-Difluorobenzyl)-5-fluoroindoline-2,3-dione ${ }^{\mathbf{1 0}}$ (12). To a $10 \mathrm{~mL}$ microwave vial charged with ethanol $(3 \mathrm{~mL})$ and a magnetic stir bar was added 5-fluoroisatin (0.3294 g, $1.99 \mathrm{mmol})$, DBU (329 $\mu \mathrm{L}, 1.1 \mathrm{eq})$ and 2,6-difluorobenzyl bromide $(0.4594 \mathrm{~g}, 1.1 \mathrm{eq})$. The reaction vessel was sealed and heated under microwave irradiation in standard mode for $25 \mathrm{~min}$ at $120{ }^{\circ} \mathrm{C}$ with a pre-stirring of $30 \mathrm{sec}$. After cooling to $\mathrm{rt}$, the reaction vessel was placed in the freezer overnight and then vacuum filtered to afford a dark red solid $(0.2133 \mathrm{~g}, 37 \%)$ : $\mathrm{mp} 132-134{ }^{\circ} \mathrm{C}$. The filtrate was then evaporated under reduced pressure to afford a red oil which was purified by silica gel chromatography (hexanes/EtOAc, $70: 30)$ to give additional product $(0.2612 \mathrm{~g})$ for a combined overall yield of $82 \%$; ${ }^{1} \mathrm{H}$ NMR (300 MHz, DMSO): $\delta .7 .60$ (ddd, $J=2.8 \mathrm{~Hz}, J=8.7 \mathrm{~Hz}, 1 \mathrm{H}$ ), $7.49(\mathrm{dd}, J=2.7 \mathrm{~Hz}, J=7.0 \mathrm{~Hz}, 1 \mathrm{H}), 7.44(\mathrm{dd}, J=1.7 \mathrm{~Hz}, J=6.8 \mathrm{~Hz}, 1 \mathrm{H}) 7.15$ (t, 3H), 7.25 (dd, $J=2.7 \mathrm{~Hz}, J=8.6 \mathrm{~Hz}, 1 \mathrm{H}), 6.98(\mathrm{t}, J=8.1 \mathrm{~Hz}, 1 \mathrm{H}), 6.91(\mathrm{dd}, J=3.5 \mathrm{~Hz}, J=8.6 \mathrm{~Hz}, 1 \mathrm{H}), 4.96$ $(\mathrm{s}, 2 \mathrm{H}) ;{ }^{13} \mathrm{C}$ NMR $(75 \mathrm{MHz}$ DMSO-d 6$) \delta 182.19-182.16(\mathrm{~d}, J=2.1 \mathrm{~Hz}), 167.7,162.6-159.2$ (dd, $J=7.7 \mathrm{~Hz}), 160.0-156.8(\mathrm{~d}, J=241 \mathrm{~Hz}), 157.73-157.71(\mathrm{~d}, J=1.7 \mathrm{~Hz}), 146.56-146.54(\mathrm{~d}, J=$ $1.6 \mathrm{~Hz}), 130.9-130.6(\mathrm{t}, J=10.5 \mathrm{~Hz}), 124.41-124.0(\mathrm{~d}, J=24.1 \mathrm{~Hz}), 118.5-118.4(\mathrm{~d}, J=7.1 \mathrm{~Hz})$, 111.9-111.7 (d, $J=7.3 \mathrm{~Hz}), 111.6-111.4(\mathrm{~d}, J=17.7 \mathrm{~Hz}), 110.9-110.4$ (t, $J=18.7 \mathrm{~Hz}), 32.2(\mathrm{t}, J$ $=3.9 \mathrm{~Hz})$; $\mathrm{MS}(\mathrm{m} / \mathrm{z}) 291\left(\mathrm{M}^{+}\right), 164(100 \%)$. 


\section{Acknowledgements}

CAJ gratefully acknowledges receipt of a WSU 2012 Undergraduate Research and Independent Project Support Grant. The authors wish to thank Professor Eric Fossum for helpful discussions regarding NMR and Jenin Jaber for review of this manuscript.

\section{References}

1. Silva, J. F.; Garden, S. J.; Pinto, A. C. J. Braz. Chem. Soc. 2001, 12, 273-324. http://dx.doi.org/10.1590/S0103-50532001000300002

2. Lashgari, N.; Ziarani, G.M. Arkivoc 2012, (i), 277-320. http://dx.doi.org/10.3998/ark.5550190.0013.108

3. Pandeyal, S. N.; Smitha, S.; Jyoti, M.; Sridhar, S. K. Acta Pharm. 2005, 55, 27-46.

4. $\quad$ Liu, Y.; Wang, H.; Wan, J. Asian J. Org. Chem. 2013, 2, 374-385. http://dx.doi.org/10.1002/ajoc.201200180

5. Guo, H.; Tian, J. Chin. J. Org. Chem. 2011, 31, 1752-1760.

6. $\quad$ Evans, B. E.; Rittle, K. E.; Bock, M. G.; DiPardo, R. M.; Freidinger, R. M.; Whitter, W. L.; Lundell, G. F.; Veber, D. F.; Anderson, P. S.; Chang, R. S. L.; Lotti, V. J.; Cerino, D. J.; Chen, T. B.; Kling, P. J.; Kunkel, K. A.; Springer, J. P.; Hirshfieldt, J. J. Med. Chem. 1988, 31, 2235-2246.

http://dx.doi.org/10.1021/jm00120a002

7. Singh, G. S.; Desta, Z. Y. Chem. Rev. 2012, 112, 6104-6155. http://dx.doi.org/10.1021/cr300135y

8. MacDonald, J. P.; Badillo, J. J.; Arevalo, G. E.; Silva-Garcia, A.; Franz, A. K. ACS Comb. Sci. 2012, 14, 285-293.

http://dx.doi.org/10.1021/co300003c

9. Shmidt, M. S.; Reverdito, A. M.; Kremenchuzky, L.; Perillo, I. A.; Blanco M. M. Molecules 2008, 13, 831-840.

http://dx.doi.org/10.3390/molecules13040831

10. Bridge, T. M.; Marlo, J. E.; Niswender, C. M.; Jones, C. K.; Jadhav, S. B.; Gentry, P. R.; Plumsley, H. C.; Weaver, C. D.; Conn, P. J.; Lindsley, C. W. J. Med. Chem. 2009, 52, 3445-3448.

http://dx.doi.org/10.1021/jm900286j

11. Wee, X. K.; Yeo, W. K.; Zhang, B.; Tan. V. B. C.; Lim, K. M.; Tay, T. E.; Go, M.-L. Bioorg. Med. Chem. 2009, 17, 7562-7571.

http://dx.doi.org/10.1016/j.bmc.2009.09.008

12. Shuttleworth, S. J.; Nasturica, D.; Gervais, C.; Siddiqui, M. A.; Rando, R. F.; Lee, N. Bioorg. Med. Chem. Lett. 2000, 10, 2501-2504. 
http://dx.doi.org/10.1016/S0960-894X(00)00523-0

13. Chiyanzu, I.; Hansell, E.; Gut, J.; Rosenthal, P. J.; McKerrow, J. H.; Chibale, K. Bioorg. Med. Chem. Lett. 2003, 13, 3527-3530. http://dx.doi.org/10.1016/S0960-894X(03)00756-X

14. Clay, C. M., Abdallah, H. M.; Jordan, C.; Knisley, K.; Ketcha, D. M. Arkivoc 2012 (vi) 317-325.

http://dx.doi.org/10.3998/ark.5550190.0013.629

15. Garden, S. J.; Torres, J. C.; Da Silva, L. E.; Pinto, S. C. Synth. Commun. 1998, 28, 16791689.

http://dx.doi.org/10.1080/00397919808006872

16. Singh, P.; Sharma, P.; Amit Anand, A.; Bedi, P. M. S.; Tandeep Kaur, T.; Saxena, A. K.; Kumar, V. Eur. J. Med. Chem. 2012, 55, 455-461. http://dx.doi.org/10.1016/j.ejmech.2012.06.057

17. Singh, R. J.; Majumder, U.; Shreeve, J. M. J. Org. Chem. 2001, 66, 6263-6267. $\underline{\text { http://dx.doi.org/10.1021/jo0157674 }}$ 